\title{
The Effectiveness of Affirmation Relaxation Therapy Towards Anxiety in Pregnant Mothers on Third Trimester in Facing Labor
}

\author{
Niken Sukesi \\ Nursing Academy Widya Husada \\ Semarang, Indonesia \\ Niken.sukesih@yahoo.com
}

\begin{abstract}
Labor is a physiological process in pregnant mothers occurring in the culmination period of pregnancy. A long process of pregnancy, which will eventually lead to the delivery of one or more newborn infants, can raise fear and worries triggering the feeling of anxiety to happen to pregnant mothers. Excessive anxiety in facing labor is to be overcome with affirmation relaxation (positive thoughts) to reduce their level of anxiety. This study aimed to examine whether or not there was an effect of affirmation relaxation therapy towards anxiety in pregnant mothers on the third-trimester in facing labor. The study was a quasi experimental research approach with one group pre testpost test design with t-test paired test. Sample was taken by total sampling to18 pregnant mothers on third trimester at Puskesmas Manyaran from September to October 2016. Results indicated that the t-count was 5.169, meaning that there was an effect in the intervention of affirmation relaxation therapy towards the level of anxiety. Furthermore, the p-value was 0.000 lower than the $\alpha$ value which was 0.05 indicating that there was a significant difference. Thus, affirmation relaxation therapy can be employed to third-trimester pregnant mothers with anxiety in facing labor.
\end{abstract}

Keywords-affirmation, music therapy, pregnant mothers, third trimester, anxiety

\section{INTRODUCTION}

Pregnancy is a state requiring special concerns especially to pregnant mothers on third trimester. They always need to be in their best condition for at this state they are prone to phisiologically and psychologically drastic changes and allert them to be well-adapted towards the changes [1]. These drastic changes may result in anxiety especially in pregnant mothers on third trimester. It sure is a lot of struggle to be pregnant and giving birth to a child to every woman with nothing but fear and worries [2].

Anxiety is a natural unpleasant emotion coming with constant fear and worries [4]. The older pregnancy gets, the more pregnant mothers concern about its culmination period, and the more intensive their fear and anxiety are [5]. The common symptoms of anxiety the pregnant mothers usually experience are feeling more anxious than usual, racing heartbeats, sleep deprivation, digestive problems, and dizziness. Self-negative thoughts of worrying about childbirth and the changes during pregnancy likely trigger a decrease in pregnant mothers' self-efficacy. A low level of self-efficacy and an unsupportive environment make them apathetic, hopeless, and unable to cope with the state they are in.

Anxiety knows no age of pregnant mothers, that of pregnancy, and history of pregnancy. Therefore, an intervention or a therapy to reduce the level of anxiety in pregnant mothers needs to be conducted. The so called intervention which can be done to them during the period of facing labor is to teach them to think positively regarding labor preparations. One of which is to have faith in themselves that things coming up are the good ones. The principles of affirmations are (a) a faith that they already accomplish their main objective even before it comes true; (b) a faith to keep them strong and persistent in the process of creating a new reality, and (c) a faith to keep them focused on their objective and spark willingness [8]. The less the level of anxiety was, the less the intensity of pains they bore during labor, and the less the occurrence of prolonged labor and other complications was.

Another study carried on by Yusuf (2010) showed that the affirmation relaxation therapy practiced to those suffering from nasopharyngeal cancer was able to help them in Room THT RSUD Dr. Soeotomo Surabaya in enhancing their self-efficacy so that they were able to sincerely and wholeheartedly accept things befalling them and the feeling of calm which in fact is crucial to peacefully and purposefully live their life [10] Having positive thoughts for pregnant mothers will make the negative ones vanish so they will be more relaxed and less anxious. Affirmations are confirmed to have positive consequences in lessening heart frequency, anxiety, depression, and blood pressure and relieving pains. Music also stimulates fun sensation resulting in endorphin release [11]. This study aimed to examine whether or not there was an effect of affirmation relaxation therapy towards anxiety in pregnant mothers on the third-trimester in facing labor.

\section{MethodS}

The study was a quasi experimental research approach with one group pre test-post test design aiming at revealing the cause and effect without the involvement of a control group. The population was all pregnant mothers on third trimester having Ante Natal Care (ANC) at Puskesmas MANYARAN from September to October 2016 which were 18 people which also became the sample as it was taken by total sampling. They agreed to be the subject of the study and signed an informed consent form. Then, they did a pre-test to determine their level 
of anxiety. After the pre-test, they underwent positive affirmations and the post-test was in order. T-test paired test was employed to do the test analysis. The independent variable in this study was affirmation relaxation therapy and the dependant variable was the anxiety in pregnant mothers on third trimester.

The instrument administered in this study was Zung-Self Rating Anxiety Scale (ZSAS) to measure levels of anxiety in patients who have anxiety-related symptoms developed by William W.K Zung. The scale focused on the most common symptoms of the most common anxiety suited with the one experienced by pregnant mothers in labor preparation. The questionnaire covered 20 statements on Likert scale about the symptoms of anxiety. The anxiety scale was $20-80$ with the grouping of 20-40 low anxiety, 45-59 moderate one, and 60-80 high one

\section{RESULTS}

TABLE I. AGE CHARACTERISTIC FREQUENCY DISTRIBUTION IN PREGNANT MOTHERS ON THIRD TRIMESTER

\begin{tabular}{ccc}
\hline Age & Frequency & Percentage \\
\hline$<25$ years & 6 & $33 \%$ \\
25-30 years & 7 & $39 \%$ \\
31-35years & 3 & $17 \%$ \\
$>36$ years & 2 & $11 \%$ \\
\hline Total & 18 & $100 \%$
\end{tabular}

Table 1 showed that the oldest pregnant mothers on third trimester were 25 - 30 years old which were 7 respondents (39\%).

TABLE II. PREGNANCY HISTORY CHARACTERISTIC FREQUENCY DISTRIBUTION IN PREGNANT MOTHERS ON THIRD TRIMESTER

\begin{tabular}{ccc}
\hline Pregnancy & Frequency & Percentage \\
History & & \\
Problematic & 2 & $12 \%$ \\
Non- & 16 & $88 \%$ \\
Problematic & & \\
\hline Total & 18 & $100 \%$ \\
\hline
\end{tabular}

Table 2 indicated that the highest non-problematic pregnancy history was 16 respondents $(89 \%)$.
TABLE III. Education Characteristic Frequency Distribution in Pregnant Mothers on Third Trimester

\begin{tabular}{ccc}
\hline Education & Frequency & Percentage \\
\cline { 1 - 2 } Elementary & 5 & $28 \%$ \\
School & & \\
High School & 12 & $67 \%$ \\
University & 1 & $5 \%$ \\
\hline Total & 18 & $100 \%$ \\
\hline
\end{tabular}

Table 3 presented the fact that most of the pregnant mothers on third trimester were high school graduates which were 12 respondents $(67 \%)$.

TABLE IV. NUMBER OF PREGNANCY CHARACTERISTIC FREQUENCY DISTRIBUTION IN PREGNANT MOTHERS ON THIRD TRIMESTER

\begin{tabular}{ccc}
\hline $\begin{array}{c}\text { Number of } \\
\text { Pregnancy }\end{array}$ & Frequency & Percentage \\
\hline $\begin{array}{c}\text { The First } \\
\text { Pregnancy }\end{array}$ & 10 & $55 \%$ \\
The Second & 8 & $45 \%$ \\
Pregnancy & & \\
\hline Total & 18 & $100 \%$ \\
\hline
\end{tabular}

Table 4 revealed the fact that those having the first pregnancy were more than a half of all respondents which were $10(55 \%)$

TABLE V. ANXIETY FREQUENCY DISTRIBUTION BEFORE AND AFTER THE INTERVENTION OF AFFIRMATION THERAPY IN PREGNANT MOTHERS ON THIRD TRIMESTER

\begin{tabular}{|c|c|c|c|c|}
\hline \multirow[t]{2}{*}{$\begin{array}{l}\text { Level of } \\
\text { Anxiety }\end{array}$} & \multicolumn{2}{|c|}{$\begin{array}{c}\text { Before } \\
\text { Affirmation } \\
\text { Therapy }\end{array}$} & \multicolumn{2}{|c|}{$\begin{array}{c}\text { After } \\
\text { Affirmation } \\
\text { Therapy }\end{array}$} \\
\hline & $\mathrm{n}$ & $\%$ & $\mathrm{n}$ & $\%$ \\
\hline $\begin{array}{l}\text { Low } \\
\text { Anxiety }\end{array}$ & 4 & $22 \%$ & 15 & $83 \%$ \\
\hline $\begin{array}{l}\text { Moderate } \\
\text { Anxiety }\end{array}$ & 14 & $78 \%$ & 3 & $17 \%$ \\
\hline Total & 18 & $100 \%$ & 18 & $100 \%$ \\
\hline
\end{tabular}

Table 5 indicated that there was a difference in the level of anxiety before and after affirmation therapy. Before the therapy, there were 14 respondents $(77 \%)$ having moderate 
anxiety. The number turned into 15 respondents (83\%) with those having low anxiety.

TABLE VI. ANXIETY DIFFERENCE TEST BEFORE AND AFTER THE INTERVENTION OF AFFIRMATION RELAXATION THERAPY

\begin{tabular}{lccccc}
\hline Variable & \multicolumn{3}{c}{ Mean } & & \\
\cline { 2 - 5 } & $\begin{array}{c}\text { Pre- } \\
\text { test }\end{array}$ & $\begin{array}{c}\text { Post- } \\
\text { test }\end{array}$ & $\mathrm{t}$ & $\mathrm{P}$ & \\
\hline Anxiety & 1.7 & 1.1 & 5,169 & 0.000 \\
\hline
\end{tabular}

Table 6 depicted the mean difference before and after affirmation relaxation therapy. Before the therapy, the mean was 1.7 while after the therapy, the mean was 1.1 . The mean difference was 0.6. The analysis showed that the t-count was 5.169 (higher than the t-table which is 2.109), meaning that there was an effect in the intervention of affirmation relaxation therapy towards the level of anxiety. Furthermore, the p-value was 0.000 lower than the $\alpha$-value which was 0.05 indicating that there was a significant difference.

\section{DISCUSSION}

The distribution of the respondents was based on demographic data with most of the respondents are 25-30 years old (39\%). The level of anxiety is strongly influenced by age factor. Mature-aged pregnant mothers with the most physical and psychological preparations in facing labor experience lower level of anxiety than those aging less than 25 or more than 35 years old. Besides, the older a pregnant woman is, the more the experience she perceives. This study was conducted to young-mature-aged pregnant mothers. This may influence the experience and knowledge they hold [12]. Also, youngmature age is a period for pregnant mothers to adapt to new patterns of life, one of which is to adjust to problems in facing labor [13].

$67 \%$ of the respondents in this study are high school graduates with no problems in their previous pregnancy $(89 \%)$ and more than a half of the respondents experience the pregnancy as their first $(55 \%)$ or so we call it primigravida. With most of the respondents being high-school-graduates, it eases those with anxiety to understand affirmations when they are employed. One with higher education can easily grasp new knowledge and quickly adapt to new surroundings [13]. Anxiety is a response which can be learned. Hence, the higher the education one has, the more quality and the more mature one's intellect will be. On the contrary, lower education will contribute to stress, anxiety, and lack of knowledge [16].

The result of this study indicated that the number of the respondents experiencing moderate level of anxiety in facing labor before affirmation relaxation therapy was $77 \%$. After the therapy, the anxiety turned into the low level one with $83 \%$ of the respondents while the other $17 \%$ was still experiencing moderate level of anxiety

Anxiety may subside if the pregnant mothers yield effective coping which can be obtained from performing affirmation relaxation therapy to make them think positively towards their pregnancy. Effective coping is required to reduce the level of anxiety. One may overcome his or her anxiety by utilizing the source of coping in their surroundings. The so called source of coping is the ability to solve problems [4]. The fact that there were $17 \%$ respondents still feeling moderate level of anxiety was due to multi-factors causing anxiety in pregnant mothers. Each pregnant mother may also undergo different causes with biological and psychological factors being the most influential ones. [3].

The analysis showed that the t-count was 5.169 (higher than the t-table which is 2.109), meaning that there was an effect in the intervention of affirmation relaxation therapy towards the level of anxiety. Furthermore, the p-value was 0.000 lower than the $\alpha$-value which was 0.05 indicating that there was a significant difference between the level of anxiety before the intervention of affirmation relaxation therapy and the one after the intervention of. To conclude, the intervention of effective affirmation relaxation therapy can turn negative thoughts into positive ones. This study is in accordance with the result of the study conducted by Kholida stating that training to think positively can decrease the level of stress [17]. Another study in regard to self-affirmation was also done by Jessop et al (2013). The study shows that respondents with the intervention of self-affirmation display more positive attitude and much better control of perception compared to those with no intervention [18].

\section{CONCLUSION}

Affirmation relaxation therapy helps pregnant mothers on third semester decrease the level of anxiety leading to the increment of positive self-acceptance and feeling of calm in the process of facing labor. This also induces the decrement of prolonged, yet smooth pregnancy.

Nursing professions should employ the practice of affirmation relaxation therapy to pregnant mothers on third trimester, for it makes it possible for them to generate positive coping and the faith of bearing the ability to face labor for it to occur with no problems or difficulties.

Medical institutions should provide a vacant and soundproof room to practice affirmation relaxation therapy because the process calls for a comfortable and calm atmosphere.

\section{REFERENCES}

[1] Sulistyawati, A.Asuhan Kebidanan Pada Masa Kehamilan. Jakarta: Salemba Medika. 2012

[2] Umami R, Puspitasari N. 2007. Peran Suami Selama Proses Kehamilan Sampai Nifas Istri. The Indonesian Journal Of Public Health. Vol. 3, No. 3, Maret 2007: 101-107.

[3] Bobak. Buku Ajar Keperawatan Maternitas. Jakarta: EGC. 2006

[4] Stuart. Buku Saku Keperawatan Jiwa. Jakarta: EGC. 2007

[5] Aprianawati, R.B. Hubungan antara Dukungan Keluarga dengan Kecemasan Ibu Hamil Menghadapi Kelahiran Anak Pertama pada Masa Triwulan Ketiga. Yogyakarta: Universitas Gajah Mada. 2007 
[6] Hidayat. Pengantar Kebutuhan Dasar Manusia Buku I.Jakarta: Salemba Medika. 2006

[7] Alwisol. Psikologi Kepribadian Edisi Revisi. Malang: Penerbit Universitas Muhammadiyah Malang. 2004

[8] Adhi. Sukses dalam kegagalan. Jakarta: PT Elex Media Komputindo kelompok gramedia. 2009

[9] Analia (2016). Pengaruh Pemberian Terapi Musik Klasik dalam Menurunkan Tingkat Kecemasan Ibu Hamil Menjelang Persalinan. Jurnal Majority. Vol 5. N0 1. Diterbitkan Februari 2016. http://jukeunila.com/wp-content/uploads/2016/02/2-1.pdf. Diakses tanggal 10 Maret 2017

[10] Yusuf. (2010). Relaksasi afirmasi meningkatkan self efficacy Pasien kanker nasofaring. Jurnal Ners Vol. 5 No. 1: 21 28.https://www.researchgate.net/publication/309134545_relaksasi_afirm asi_meningkatkan_self_efficacy_pasien_kanker_nasofaring_relaxation_ affirmaton_technique_increase_self_efficacy_of_patients_with_nasopha ring_cancer. diakses tanggal 10 Maret 2017

[11] Potter dan Perry. Buku Ajar Fundamental Keperawatan volume I Edisi 4. Jakarta: EGC. 2006
[12] Koentjaraningrat. Pengantar Ilmu Antropologi. Jakarta. Rineka Cipta. 2009

[13] Hurlock,E.B. Psikologi Perkembangan. Jakarta. EGC. 1980.

[14] Notoadmojo, S. Metodologi Penelitian Kesehatan. . Jakarta : Rineka Cipta. 2010

[15] Rina (2015). Hubungan Intensitas Hypnobirthing dengan tingkat Kecemasan Ibu Hamil Menghadapi Persalinan di BPM Tri Rahayu Setyaningsih Sleman.

[16] http://opac.say.ac.id/734/1/Naskah\%20publikasi.pdf. Diakses tanggal 25 Maret 2017

[17] Hendrick V, Psychiatric disorders pregnancy and the postpartum principles and treatment. New Jersey: Humana Press. 2006

[18] Kholida, N.E \& Alsa.A. Berpikir positif untuk menurunkan stress psikologis . Jurnal psikologi Volume 39, 170 : 67-75. 2012

[19] Jannah. Penerapan Teknik Berpikir Positif dan Afirmasi Positif pada Klien Ketidakberdayaan dengan Gagal Jantung Kongestif. Jurnal Keperawatan Jiwa. Volume 3, No. 2, November 2015; 114-123. http://ppnijateng.org/wp-content/uploads/2016/08/Keperawatan-Jiwa_place-PDF-vol-3-No-2-rev.30-39.pdf. diakses tanggal 25 Maret 2017 